\title{
Metalik nanopartiküllerin hedeflendirilmesi
}

\author{
Targeting of metallic nanoparticles \\ Emel Öykü Çetin Uyanıkgil ${ }^{1} \quad$ Derya Selcen SALMANOĞLU² \\ ${ }^{1}$ Ege Üniversitesi Eczacılık Fakültesi Farmasötik Teknoloji Anabilim Dalı, Bornova, İzmir \\ ${ }^{2}$ Ege Üniversitesi Fen Bilimleri Enstitüsü Biyomedikal Teknolojiler Anabilim Dalı, İzmir
}

\section{Özet}

Hedeflendirilmiş ilaç taşıyıcı sistemlerin amacı, terapötik etkinliği artırmak, etkin maddenin kontrollü salımını sağlamayı, ilaç lokalizasyonunu iyileştirmeyi ve ilaç toksisitesini azaltmayı amaçlamaktadır. $\mathrm{Bu}$ bakımdan, metalik nanopartiküller, çeşitli hastalıkların tedavisinde bu amaçların yerine getirilmesinde yeni bir boyut sunar ve bu partiküllerin sadeliği ve hazırlanma kolaylığı, bilim dünyasının ilgisine neden olmuştur. Bu derlemenin amacı, metal nanopartiküllerin özelliklerini, sınıflandırılmalarını ve hedeflendirilmiş ilaç taşımada kullanımını özetlenmesi ve metalik nanopartiküllerin ilaç taşıyıcı sistem olarak kullanımının literatür eşliğinde tartışımasıdır.

Anahtar Sözcükler: Metalik nanopartikül, hedeflenme, kanser.

\begin{abstract}
The aim of targeted drug delivery systems are increase therapeutic efficacy, improve drug localization, provide controlled release of the active substance and decrease drug toxicity. In this respect, metallic nanoparticles provide a new dimension in the achievement of these aims in the treatment of several diseases and the simplicity and ease of preparation of these particles have attracted the attention of the scientific community.

The aim of this review is summarize the properties, classification and use of metal nanoparticles and discuss the use of metallic nanoparticles as drug delivery systems in the literature.
\end{abstract}

Keywords: Metallic nanoparticle, targeting, cancer.

\section{Giriş}

Nanoteknoloji, metrenin milyarda biri skalasında yer alan; nanometre boyutlarındaki $\left(10^{-9} \mathrm{~m}=1\right.$ $\mathrm{nm}$ ) maddeyle ilgilenen bilimdir ve aynı zamanda maddeyi atomik ve moleküler ölçekte manipüle etme çalışmasıdır. Yeni bir terim olmakla birlikte, daha verimli teknolojinin gelişimi için yaygın olarak kullanılmaktadır. Nanoteknoloji alanındaki gelişmeler, tıp ve eczacılıktaki uygulamaları yirminci yüzyılda devrim yaratmıştır. Son yıllarda nanoteknoloji, biyoteknoloji, ilaçların hedeflendirilmesi, gen ve ilaçlar için taşıyıcı gibi uygulamaları nedeniyle endüstriyel sektörler tarafından oldukça benimsenmiştir (1-5). Sonuç olarak, geniş bir uygulama yelpazesi ile topluma

\footnotetext{
Yazışma Adresi: Emel Öykü Çetin Uyanıkgil

Ege Üniversitesi Eczacılık Fakültesi Farmasötik Teknoloji

Anabilim Dalı, Bornova, İzmir

E-mail: emel.oyku.cetin@ege.edu.tr

Makalenin Geliş Tarihi: 23.12.2019 Kabul Tarihi: 18.02.2020
}

önemli bir etki yapma potansiyeline sahiptir. Yeni olmasına rağmen, nanomateryallerin tarihi, ünlü fizikçi Richard P. Feynman'ın nanomateryallerin ortaya çıkmasını öngördüğü 1959'a kadar uzanmaktadır. Feynman konuşmasının birinde, "aşağıda daha çok yer var" diyerek nano seviyede ölçeklenmenin gelecekteki teknolojinin ve ilerlemenin anahtarı olacağını ileri sürmüştür.

Bir nanopartikül (NP), bir nano yapı yapımında en temel komponenttir ve nanopartikülün spesifik bir tanımı olmamakla birlikte, bunlar genellikle $1 \mathrm{~nm}$ ila $100 \mathrm{~nm}$ arasındaki partiküller olarak adlandırılmaktadır. Newton'un hareket kanunlarıyla tanımlanan günlük objelerin dünyasından çok daha küçüktür. 
Ancak bir atomdan veya kuantum mekaniğinin yönettiği basit bir molekülden daha büyüktür.Küçük partikül boyutu, yüksek stabilite, ayarlanabilir hidrofilik-hidrofobik balans ve hedef spesifik lokalizasyon için yüzey özellik kabiliyeti gibi benzersiz fonksiyonel karakterler nedeniyle dünya çapında büyük ilgi görmektedirler $(6,7)$.

Nanopartiküller, farklı veriliş yolları için uygunluk, taşıma kapasitelerinin yüksekliği, ilaçların raf ömürlerinin arttırıması, ilaç salım sistemlerinin salım ve kontrol etme yeteneği, iki veya daha fazla ilacın birlikte taşınabilmesine olanak veren kombinasyon terapisi için uygunluğu, hem hidrofobik hem de hidrofilik ilaçların birleştirilebilmesi, ilaçların biyoyararlanımlarının arttırılması, hem görüntüleme maddeleri hem de etkin madde bağlanabilmesi gibi olağanüstü özelliklerinden dolayı, ilaç taşıma ve/veya hedeflemede kullanımları gibi birçok avantajlarından dolayı oldukça cazip hale gelmiştir (8-10).

İlaç salım sistemlerinin hedeflendirilmesi pasif veya aktif olarak gerçekleştirilebilmektedir. Pasif hedeflemede, hedef aracı olarak hiçbir ligand kullanılmaz ve hedefleme, hedef organa pasif olarak ulaşan bir makromolekül veya nanopartikül içerisine terapötik ajanın dahil edilmesiyle gerçekleştirilir. Bu stratejide, kanser dokusundaki damarların sızdıran doğası ve lenfatik sistem yetersizliği, artmış geçirgenlik ve alıkonma etkisi (EPR) olarak adlandırılan nanopartiküllerin geçirgenliğinin ve tutulumunun artması rol oynamaktadır. Bunun yanı sıra aktif hedeflendirmede, terapötik ajan veya taşıyıcı sistem, hedef aracı olarak ligand kullanılarak tümörlü dokuda over-eksprese olan hücre spesifik reseptörlere veya dokuya konjuge edilir (11). Mevcut ilaçların, fizyolojik pH'da zayıf çözünme, biyodağılım ve hücre içerisine alımı gibi problemleri çözmek için dendrimerler, lipozomlar, metalik nanopartiküller, miseller, veziküller, nanoemülsiyonlar, kuantum dotlar ve polimerik nanopartiküller gibi nanosistemler geliştirilmiştir. $\mathrm{Bu}$ nanosistemler, ilaçların kontrollü salımı ve tümör hedeflemesini arttırmak ve kemoterapi probleminden kaçınmak gibi amaçlarla kullanılmaktadır (12).

\section{Nano ölçekli ilaç taşıyıcı sistemlerin amaçları:}

a. Hedeflenen, istenen etki bölgelerinde ilaç konsantrasyonunu arttırmak; ilacın sistemik seviyelerini ve sağlıklı dokulardaki toksik etkilerini azaltmak. b. Parenteral ilaç uygulamasını kolaylaştırmak için çözünürlüğü artırmak.

c. Etki bölgesinde sabit terapötik dozu korumak için sıfır dereceli salım kinetiği ile sonuçlanan sabit ilaç taşıma hızı.

d. Illacın yarı ömrünü artırmak için azaltılmış klerens.

e. Degradasyon azaltmak ve ilaç etkisini artırmak için ilaç stabilitesini arttırma.

f. Kan-beyin bariyeri ve kan-koklea bariyeri boyunca ilaç taşıma, nano ölçekli ilaç taşıyıcı sistemlerin amaçları arasında yer almaktadır.

Hedeflendirilmiş ilaç taşımada metalik NP'ler, çeşitli hastalıkların tedavisinde yeni bir boyut sunmuştur. Metalik nanopartiküller asırlardır bilim insanlarını büyülemektedir. Nanoteknoloji alanındaki büyük potansiyelleri nedeniyle şu anda biyomedikal bilimlerde, mühendislikte oldukça yoğun olarak kullanılmaktadır. Son zamanlarda, metalik nano yapıların manyetik, katalitik, elektriksel ve optik tüm özellikleri şekil ve boyutlarından etkilendiğinden bu nano yapıların şeklinin ve boyutunun kontrol edilmesine ilgi gösterilmiştir.

Metalik nanopartiküller, tanısal analizler $(13,14)$, radyoterapinin arttırılması ve termal ablasyon gibi çeşitli biyomedikal uygulamalarda sayısız fırsat sunan çok amaçlı ajanlardır (15).

Bugün bu materyallerin biyoteknoloji, hedeflendirilmiş ilaç taşıma, gen ve ilaç taşıma aracı ve daha da önemlisi tanısal görüntüleme gibi geniş bir uygulama yelpazesi vardır. Bu nano taşıyıcılar, aktif veya pasif olarak hedeflendirildiklerinde, ultrason (US), X-ışını, bilgisayarlı tomografi (CT), pozitron emisyon tomografisi (PET), manyetik rezonans görüntüleme (MRI), optik görüntüleme ve yüzeyle güçlendirilmiş Raman görüntüleme (SERS) gibi çeşitli teknikleri kullanarak görüntüleme probları gibi davranacak şekilde tasarlanabilirler (16). Ayrıca, metalik NP'lerin yüzeylerinin polietilen glikol gibi biyo uyumlu polimerlerle yüzey modifikasyonu, ilaçların etki süresinin uzatılmasına yardımcı olur ve ayrıca hedeflenmiş gen taşıma ve susturma amaçları için kullanılmaktadırlar $(17,18)$.

Metalik NP'ler, şekil (nanokabuk, nanorod gibi), boyut (1-100 nm) ve kompozisyonlarına (çekirdek/kabuk ya da alaşımlı soy metal gibi) göre istenen dalga boylarına kolayca uyarlanabilen yüksek oranda ayarlanabilir optik 
özellikler gösterir. Bu da onları natif doku altında görüntüleme ve fototermal uygulamalar için uygun hale getirmektedir.

Ayrıca, soy metal NP'leri, ışığı veya radyo frekanslarını verimli bir şekilde ısıya dönüştürerek hedeflenen kanser hücrelerinin termal ablasyonunu sağlamaktadır $(19,20)$.

\section{Metalik Nanopartiküllerin Sınıflandırılması}

Metalik NP'ler, saf metallerden (örneğin, altın, platin, gümüş, titanyum, çinko, seryum, demir ve talyum) veya bunların bileşiklerinden (örneğin, oksitler, hidroksitler, sülfitler, fosfatlar, florürler ve klorürler) yapılmış submikron ölçekli maddelerdir (21).

Tablo-1'de gösterildiği gibi farklı özelliklerine göre farklı sınıflamalar bulunmakla birlikte en güncel haliyle nanopartikülleri ve nano yapılı materyaller, dört materyal-bazlı kategori halinde sınıflandırılabilir $(22,23)$ :

Tablo-2 de belirtildiği gibi çeşitli nano materyaller arasında metalik nanopartiküller belirgin avantajlar sunmalarına rağmen bazı dezavantajlara da sahiptirler $(24,25)$.

Tablo-1. Nanopartiküllerin Sınıflandırılması (23).

\begin{tabular}{|c|c|c|c|}
\hline \multicolumn{4}{|c|}{ Nanopartiküller- Nano yapılı materyaller } \\
\hline $\begin{array}{l}\text { Karbon bazlı } \\
\text { nanomateryaller }\end{array}$ & $\begin{array}{l}\text { İnorganik bazlı nano } \\
\text { materyaller }\end{array}$ & $\begin{array}{l}\text { Organik bazlı } \\
\text { nanomateryaller }\end{array}$ & $\begin{array}{l}\text { Kompozit bazlı } \\
\text { nanomateryaller }\end{array}$ \\
\hline Fullerenler (C60) & Altın & Dendrimerler & Kitosan \\
\hline $\begin{array}{l}\text { Karbon nanotüpler } \\
\text { (CNT) }\end{array}$ & Gümüş & Miseller & Polilaktik asit \\
\hline $\begin{array}{l}\text { Karbon } \\
\text { nanofiberler }\end{array}$ & Titanyum dioksit & Lipozomlar & Hidroksi etil metakrilat \\
\hline Grafen (Gr) & Çinko oksit & Polimer nanopartiküller & \\
\hline & Demir oksit & & \\
\hline & Silisyum & & \\
\hline & Kuantum noktalar & & \\
\hline
\end{tabular}

Tablo 2. Metalik nanopartiküllerin avantaj, dezavantaj ve karakterizasyonu

\begin{tabular}{|c|c|c|}
\hline \multicolumn{3}{|c|}{ Metalik Nanopartiküller } \\
\hline Avantajları & Dezavantajları & Karakterizasyonu \\
\hline Artmış rayleigh saçılımı & Nanopartiküllerin kararsızlığı & Absorbans Spektroskopisi \\
\hline $\begin{array}{l}\text { Yüzeyce güçlendirilmiş raman } \\
\text { saçılması }\end{array}$ & Safsızlık & Infrared Spektroskopisi \\
\hline Güçlü plazma emilimi & $\begin{array}{l}\text { Nanomalzemelerin biyolojik olarak } \\
\text { toksik olmaları }\end{array}$ & Geçirimli Elektron mikroskobu (TEM) \\
\hline Biyolojik sistemleri görüntüleme & Patlayıcı olmaları & Atomik Kuvvet Mikroskobisi (AFM) \\
\hline \multirow[t]{4}{*}{$\begin{array}{l}\text { Nano skaladaki metalik substrat } \\
\text { hakkındaki kimyasal bilgileri } \\
\text { belirleme }\end{array}$} & Sentez zorluğu & $\begin{array}{l}\text { X-ışınları Kırınım Difraktometresi } \\
\text { (XRD) }\end{array}$ \\
\hline & & $\begin{array}{l}\text { Fourier Dönüşümlü Infrared } \\
\text { Spektroskopisi (FTIR) }\end{array}$ \\
\hline & & $\begin{array}{l}\text { Uzamış X-ışınları Soğurumlu Ayrıntılı } \\
\text { Yapı (EXAFS) }\end{array}$ \\
\hline & & $\begin{array}{l}\text { X ışını Fotoelektron Spektroskopisi } \\
\text { (XPS) }\end{array}$ \\
\hline
\end{tabular}


Ilaç Taşıyıcı Olarak Metalik Nanopartiküller:

İdeal nano-ölçekli ilaç taşıma sistemi, konjuge veya ilaç bağlı taşıyıcı kompleksin istenen hedefe ulaşmasını ve etki etmesini sağlar. İlaçnanotaşıyıcı kompleksin hedeflendirilmesi, aktif olabilir ki bu şekilde kompleks, hedef dokunun reseptörüne veya epitopuna spesifik bir ligand içerir. Pasif hedeflemede bu kompleksler tümör ve iltihaplı dokular gibi aşırı sızdıran mikrovasküler bölgelerde difüze olur ve birikirler. Özellikle kanserde, vasküler endotel büyüme faktörünün (VEGF) over-ekspresyonu gibi anjiyogenezi düzenleyen faktörlerdeki dengesizlik hem artmış vasküler geçirgenlik hem de düzensiz tümör-damar yapılanması ile sonuçlanır.

İlaç taşımada kullanılan herhangi bir nano materyalin temel özelliği, biyouyumluluk, biyobozunurluktur, bu şekilde boş taşıyıcı, nontoksik bileşenlere bozulur veya metabolize edilir ve dolaşımdan temizlenir.

$\mathrm{Bu}$ materyaller boyuta göre temizlenir. Küçük partiküller $(0-30 \mathrm{~nm})$ renal atılım ile hızla temizlenir. $30 \mathrm{~nm}$ 'den büyük nanotaşıyıcılar karaciğerde (Kupffer hücreleri) ve dalakta bulunan fagositotik temizleyiciler olarak görev yapan makrofajlarla temizlenir (26).

Kanserde klinik olarak kullanılan kemoterapötik ilaçlar, tümör dokular ile birlikte sağlıklı dokulara da kolayca difüze olan ve dolayısıyla vücuda eşit bir şekilde dağılabilen ve nispeten kısa yarı ömürlü ve yüksek klerens oranına sahip olan düşük moleküler ağırıklı bileşiklerdir. Hedef bölgeye ulaşan ilaç miktarı çok azdır bu da terapötik etkinliği azaltır ancak olası ilaç direnci riskini de içeren yan etkiler artar.

Konvansiyonel kemoterapötiklerle ilişkili problemlerin üstesinden gelmek için, fonksiyonelleştirilmiş metalik NP'leri, hedef bölgeye özgüllüğü arttırmak için ilaç moleküllerinin vektörleri gibi işlev görürler. Metalik NP'lerin performansı, NP'lerin büyüklüğüne, ilaç salım hızına ve partikül bozunma hızına bağlıdır (27).

Yıllardır, altın nanopartiküllerin (AuNP) ve çinko oksit nanopartiküllerin paklitaksel (28) gibi antikanser ilaçların ve sisplatin, oksiplatin gibi platin bazlı kemoterapötiklerin taşınmasında $(29,30)$ kullanımı kapsamlı bir şekilde araştırılmaktadır.

Gibson ve ark. kemoterapötik bir ilaç olan paklitaksel ile kovalent olarak fonksiyonel- leştirilmiş $2 \mathrm{~nm}$ AuNP'lerin ilk örneğini araştırmışlardır (31).

Metalik NP'ler, hedeflendirilmiş ilaç taşıma ve ilaç geçirgenliğinin arttırıması veya ilk geçiş metabolizmasının üstesinden gelinmesi gibi olanaklar sağlamaktadır. Bu nanopartiküller, ilaç ve gen taşıma uygulamalarında in vivo sirkülasyonu uzatmak için biyolojik olarak uyumlu olan polimerler (polietilen glikol) ile spesifik olarak farklı hücreleri hedeflemede peptidler, antikorlar ve DNA/RNA gibi çeşitli ajanlarla kolayca konjuge edilebilirler.

Qian ve ark, 2008 yılında kanser hücrelerinde ve ksenograft fare modellerinde AuNP'lerin kullanımını denenmişler ve biyouyumlu olan ve SERS ile karakterize edilen, tümöre hedeflendirilen (in vivo) non-toksik PEG AuNP'lerin kullanımını rapor etmişlerdir (32).

Ancak ilaç taşımada kullanılan metalik nanopartiküller, ilaç uygulamasından sonra inert ve biyouyumlu olmasına rağmen, partiküllerin bir kısmı vücutta tutulabilir, bu da toksisiteye neden olabilir.

Hidrofobik ilaçların uygulamaları moleküler enkapsülasyon gerektirir ve nano boyutlardaki partiküllerin özellikle retiküloendotel sistemden kaçmada etkili olduğu bulunmuştur (33).

Termosensitif hidrojel matrisle kaplanmış altınaltın sülfür nanokabuklar, fototermal modüle edilmiş ilaç taşıma sistemi olarak geliştirilmiştir (34). Bu nanokabuk-kompozit hidrojeller, temel olarak yakın infrared (NIR) ışığını güçlü bir şekilde absorbe eder ve tekrarlanan NIR ışımasına yanıt olarak hidrojel matrisi içinde tutulan çözünür materyalin çoklu ani salımı için tasarlanmıştır. 2009 yılında Yavuz ve ark. da benzer bir çalışma yapmıştır (35).

Radyoterapi, kanser tedavisinde malign hücrelerin proliferasyonunu kontrol etmek için iyonlaştırıcı radyasyon kullanır. Bununla birlikte, letal radyasyon dozu tümöre taşınırken yakındaki sağlıklı dokuları korumak radyasyon terapisinin en büyük zorluğudur. Metalik NP'ler, daha düşük radyasyon dozlarıyla hedeflendirilmiş radyasyon sağlayan ve dolayısıyla sağıklı dokuları hasardan koruyan antenler gibi davranabilirler.

Işınlama ayrıca NP'leri aktive etmek ve sitotoksik salımı ayarlamak için de kullanılabilir. İyonlaştırıcı radyasyonlar, su moleküllerinin radyolizi yoluyla reaktif oksijen türleri (ROS) üretir. Eşleşmemiş elektron nedeniyle, DNA'da güçlü tahrip edici 
etkiye sahiptir. Metalik NP'lerin radyasyonun hedeflemesini arttırmada çeşitli mekanizmaları vardır. Metalik NP'leri, iyonlaştırıcı radyasyonlardan (AuNP'ler) intraselüler ROS üretimini, tümör hücrelerinde oksidatif stresi ve spesifik apoptozu arttırır; klonojenik sağ kalımı azaltır (Gümüş NP'ler). Radyoterapide altın, gümüş, platin, çinko oksit, titanyum dioksit vb. gibi çeşitli metalik NP'ler kullanılmaktadır. Metal NP'lere, ilginç optik, elektriksel ve iletken özelliklerinden dolayı, radyosensitizasyon nanotıpta yoğun ilgi gösterilmiştir. Bununla birlikte, yüksek atom numarası ve kütle enerji katsayısı nedeniyle gümüş NP'ler (AgNP) ve AuNP'ler, kanser görüntüleme ve tedavide radyosensitizasyon uygulamalarında diğer metal NP'lerden üstünlük göstermektedir (27).

\section{Metalik İnorganik Nanopartiküller}

\section{Altın Nanopartiküller}

Altın, en önemli soy elementtir. Kütle (bulk) veya moleküler skaladaki altının aksine, nano ölçekli altın; kimyacılar, fizikçiler ve şimdi biyomedikal uygulayıcılar için onları oldukça popüler çalışma objeleri haline getiren canlı renkler sergileyebilir. Ancak güzelliklerinin ötesinde, AuNP'ler diğerlerinden temelde farklı olan özellikler sergilerler. AuNP'ler ilk olarak Michael Faraday tarafından tanımlanmıştır (36).

AuNP'lerin yüzeyi, tümör spesifik hedefleme için amin ve tiyol grupları tarafından kolayca modifiye edilebilir. Bu nanopartiküller, ilaç yükleme, biyouyumlu olma, kan akışıyla hedeflenen bölgeye kolayca ulaşma, normal hücrelere sitotoksik olmama, çeşitli yöntemlerle sentezlenebilme ve ilaçların verimliliğini arttırma gibi benzersiz fiziksel ve kimyasal özelliklere sahiptir.1nm'den 100 nm'ye kadar çeşitli boyutlarda küresel, çubuk, kafes gibi çeşitli AuNP şekilleri kolayca sentezlenebilir. AuNP'lerin optik ve elektriksel özellikleri büyük ölçüde şekillerine ve boyutlarına bağlıdır. AuNP'ler üzerindeki negatif yük nedeniyle, ilaçlar, genler ve hedeflendirilmiş ligandlar gibi biyomoleküller ile kolayca fonksiyonelleştirilebilirler.

AuNP'ler farklı yüzey etkisine, ultra küçük boyuta, makroskopik kuantum tünelleme etkisine ve yüzey plazmon rezonans (SPR) bantlarının varlığına sahiptir. Tüm bu partiküler özellikler, AuNP'lerin biyosensör, moleküler görüntüleme, ilaç taşıyıcıları içeren çeşitli biyomedikal uygulamalar için potansiyeli en yüksek malzeme haline gelmesine neden olmuştur.

Son zamanlarda AuNP'ler çeşitli yükleri hedeflerine taşınmada cazip bir aday olarak ortaya çıkmıştır. AuNP'ler ilaç taşıma platformları olarak kullanım için büyük kapasiteye sahiptir. AuNP'ler hedeflerine multipl ilaç molekülü, rekombinant protein, aşı veya nükleotit taşıyabilirler. Biyolojik uyaranlar (dahili) veya ışık aktivasyonu (harici) yoluyla ilaç salımını kontrol edebilirler. AuNP'lerin ilaç molekülleri ile konjugatları, endoselüler hastalıkların tedavisinde önemli rol oynamaktadır (37).

Antibiyotikler veya diğer ilaç molekülleri, AuNP'ler ile iyonik veya kovalent bağlanma veya fiziksel absorpsiyonyoluyla doğrudan konjuge edilebilir. Örneğin yapılan bir çalışma da 13nm kolloidal Au metotreksata birleştirilmiştir (38).

Kanser hücresinin büyümesini ve çoğalmasını engelleyen folik asit analogu antikanser ilacı olarak kullanılan metotreksat molekülü, üzerindeki karboksilik gruplar AuNP'lerin yüzeyiyle birleşebilir. Aynı hacimde, AuNP'lere bağlı metotreksat konsantrasyonunun, AuNP'lerin yokluğundan daha yüksek olduğu gösterilmiştir Wang ve ark. tarafından yapılan bir çalışmada, doksorubisin (DOX), pH-duyarlı bir bağlayıcı ile 30nm AuNP'lere bağlanmıştır. Bu DOX-AuNP bağlanma, asidik organellerde DOX'un AuNP'lerden intraselüler tetiklenmiş salımına olanak sağlar. Bu, intraselüler DOX konsantrasyonunda hızlı bir artışa neden olmuş, böylece ilaca dirençli tümör hücrelerinde terapötik etkileri arttırmıştır (39).

Brown ve ark. antikanser ilaç olan oksaliplatinin aktif bileşenlerini, geliştirilmiş ilaç taşıma için AuNP'lere eklemiştir (28). Yüksek atom numaralarından dolayı, görüntüleme vektörleri ve tümör selektif fototermal terapide de kullanılabilirler (40).

Antikanser ilaçlarla konjuge edilen altın nanopartiküller, aynı serbest ilaçlarla karşılaştırıldığında tümör hücresi proliferasyonunu daha iyi inhibe ettiklerini bildiren başarılı in vitro çalışmalar yapılımıştır (41-45).

\section{Gümüş Nanopartiküller}

Gümüş, eşit sayıda pozitif iyonları ve iletim elektronları içeren serbest bir elektron sistemidir. AgNP'ler, iyi iletkenlik, kimyasal stabilite, katalitik, antibakteriyel aktivite, antifungal, antiviral, antiinflamatuvar gibi karakteristik özellikleri 
nedeniyle dikkat çekmiştir. Topikal merhemler ve yara iyileşmesi için bandajlardan kaplanmış stentlere kadar uzanan gümüş bazlı tıbbi ürünlerin, bakteriyel enfeksiyonların geciktirilmesinde ve önlenmesinde etkili olduğu kanıtlanmıştır (46).

Hibrit moleküler birimler içeren AgNP'ler, terapötik ortamlar için olağanüstü biyouyumluluk özelliğine sahip olduğundan, malignite, inflamatuvar ve enfeksiyöz rahatsızlıkları hedeflemek için optik, termal ve $\mathrm{pH}$ modülasyonlarına duyarlı ilaç taşıyıcı sistemlerin tasarımında kullanılırlar (47).

AgNP'lerin plazmonik yapısı ışığın absorpsiyonuna ve saçılımına yardımcı olur. Kanser teşhisinde, AgNP'ler tarafından absorbe edilen ışık, kanser hücrelerinin termal olarak öldürülmesini kolaylaştııırken saçılan ışık, kanser hücrelerinin görüntülenmesine yardımcı olmaktadır. Kanser terapisinde AgNP'ler hücrelere bağlandıktan sonra ROS'un susturulmasından sorumlu proteini hedefler. AgNP'ler kanser hücrelerinde, inflamatuvar yanıt, bozulma ve ardından mitokondrinin tahrip olmasına yol açan ROS birikimini indükler (48). Sadat ve ark. nekroz yerine apoptoz tarafından teşvik edilen ve meme kanseri hücrelerine antitümör ilaç taşımada önemli olan, doz sıklığını azaltan ve potent biyoyararlanım için yüksek imatinib yüklenmiş gümüş nanopartikül geliştirmişlerdir. Yeşil sentez metodu ile sentezlenmiş gümüş nanopartiküllerin, imatinibin kontrollü ilaç taşıma için potansiyel olarak faydalı olacağı sonucuna varmışlardılar (49). Goyal ve ark. konvansiyonel indirgeyici ajanları, biyouyumlu ve yapısal uyumlu şeker molekülleri ile değiştiren $\beta$-glukan kullanılarak AgNP sentezlenmişlerdir. Burada doksorubisin, AgNP içeren nanoemülsiyonlar içinde kapsüllenmiş ve mikrobiyal enfeksiyonu önleyen, kanser hücrelerinin tedavisinde oldukça faydalı olan antitümör etkinliği ile birlikte antibakteriyel etkiler sergileyen AgNPler için etkili bir nanoemülsiyon taşıma metodu geliştirilmiştir (50).

2018 yılında Sharma ve ark. tarafından yapılan in vitro çalışmalar, farklı boyutlardaki $(20 \mathrm{~nm}, 50 \mathrm{~nm}$, 100nm) AgNP'lerin glioma hücrelerinde (sıçan C6 glioma hücreleri, insan U251 ve SHG-44 glioma hücreleri) radyasyonla indüklenen nekrozu arttırdığını göstermektedir. Boyut arttıkça, AgNP'lerin performansı düşer. $20 \mathrm{~nm}$ boyutundaki
AgNP'lerin, U251 hücrelerine karşı radyasyon duyarlıı̆ı $50 \mathrm{~nm}$ ve $100 \mathrm{~nm}$ den daha iyi performansa sahip olduğu gösterilmiştir (27).

\section{Silika Nanopartiküller (SiNP'ler)}

Oral formülasyonlarda, amorf silikon dioksit $\mathrm{SiO}_{2}$ veya silika, 50 yıldan fazladır farmasötik bir eksipiyan olarak kullanılmaktadır. ABD Gıda ve İlaç İdaresi (FDA) tarafından genel olarak güvenli (GRAS) kabul edilerek sınıflandırılmıştır (51).

Biyomedikal uygulamalarda kullanılan SiNP'ler, mezoporlu, nonporlu (solid) ve her ikisinin yapısına sahip olan amorf silika nanopartiküller olarak sınıflandırılabilirler. Mezoporlar (2-50nm gözenek boyutu) ile karakterize mezoporlu silika nanopartiküller (MSN'ler), fiziksel veya kimyasal adsorpsiyona dayalı aktif yüklerin taşınmasında yaygın olarak kullanılır. Buna karşılık, gözeneksiz SiNP'ler enkapsülasyon veya konjugasyon yoluyla yüklerini taşırlar (52). Amorf silika, düşük pH'da kararlı olarak bilinmekte ve daha yüksek pH'da hızla çözünmektedir. İlaç taşıma amacıyla keşfedilen silika materyalleri arasında, MSN'ler ilaç taşıma için birçok ilgi çekici özellikler sunar. Bunlar; Sirkülasyon zamanını artıran hidrofilik yüzeye sahip olması, ayarlanabilir partikül boyutları $(50-300 \mathrm{~nm})$ ve morfolojisi (küre, çubuk), üniform ve ayarlanabilir por boyutu, geniş yüzey alanı $\left(700-1000 \mathrm{~m}^{2} \mathrm{~g}^{-1}\right)$, büyük por volümü $\left(0.6-1 \mathrm{~cm}^{3} \mathrm{~g}^{-1}\right)$, yüzey fonksiyonelleşmesi için çok yönlü silan kimyası, yüksek termal/kimyasal stabilitesi, ayarlanabilir iki fonksiyonel yüzey ile: gözenek kanallarındaki iç yüzey ve partikülün dış yüzeyi selektif fonksiyonelleştirmeye olanak sağlaması, herhangi bir bağlantısı olmayan benzersiz gözenekli yapılar, sıfır erken salınım için gerekli mükemmel bir "kapak" görevi görmesi, in vivo biyouyumluluk ve hemouyumluluğunun iyi olması, çok sayıda memeli hücresi tarafından endositoz kolaylığı ve çok düşük toksisiteye sahip olmasıdır (53).

Tüm bu özellikler, ilaç yükleme ve artan çözünürlüğün daha iyi kontrol edilmesine olanak sağlar ve ilaç moleküllerini gastrointestinal sistemin ağır koşullarından etkin bir şekilde korur (54).

Biyouyumlu, oldukça gözenekli yapısı ve modifikasyon kolaylığı dâhil olmak üzere taşıyıcı sistemler olarak birçok avantajları vardır. Arı peteğine benzer gözenekli yapısıyla mezoporlu SiNP'ler çeşitli biyoaktif molekülleri büyük miktarda yükleme kapasitesine sahiptirler. 
Titanyum dioksit ve demir oksit gibi diğer metal oksitlerle karşılaştırıldığında, silikanın biyouyumluluğunun daha iyi olduğu kabul edilir ve canlı hücreler tarafından endositoz yoluyla güvenle hücre içine alınabilir. Güçlü Si-O bağı sayesinde SiNP'leri, lipozomlara ve dendrimerlere kıyasla mekanik stres ve bozunma gibi dış uyaranlara karşı daha stabildir ve diğer taşıyıcı sistemlerde kullanılan kovalent bağlayıcılar gibi ek stabilizasyon intiyacını elimine ederler. Gözenek boyutu ve porozite gibi mezopor yapısı, ilaç boyutu ve tipine göre ayarlanabilir.

SiNP'leri kullanan çok sayıda uygulama vardır; uyaranlara duyarlı ilaç taşıma, fotodinamik terapi, ilaç ve gen taşıma, protein taşıma, teşhis ve görüntüleme, DNA ve mikroarray tespiti, radyo taşıyıcı/ radyo sensitizer olarak kullanılmaktadır (52).

Yesil-Celiktas ve ark. (2017) nöroblastoma hücreleri için taşıyıcı olarak silika-PAMAM dendrimer nanopartikül formülasyonları geliştirmişler ve kara havuç ekstresinde bulunan antosiyaninlerin nanopartiküllere enkapsülasyonu ve nöroblastomun proliferatif etkilerini inhibe etme açısından kabiliyetlerini araştırmışlardır. Bu çalışma da ilk 90 dakika etkin maddenin tampon ortamında dedekte edilmediğini, etkin maddenin nano yapı içerisine tamamen hapsolduğunu ve yüzeyde absorbe edilen hiç etkin madde olmadığını göstermişlerdir. Ekstrelerin ve enkapsüle formların sitotoksik aktivitesini farklı hücre hatlarında gözlemlemek amacıyla MCF7, Saos-2, Vero, A549, MDA-MB-231 ve NA2A hücre hatlarını sitotoksisite çalışmaları sırasında kullanılmışlar ve nanopartiküllerin ve ekstrelerin MCF-7, Saos-2, A549 ve Neuro 2A hücre hatlarında sitotoksik etkisinin olduğunu gözlemlemişlerdir (55).

Silika nanopartikülleri, kimyasal olarak inertliği, optik olarak transparanlığı ve kolayca modifiye edilebilirliği nedeniyle kanser görüntülemede büyük ilgi odağı halini almıştır. Nötral pH'da hidrofilik yüzey silanol (-Si-OH) ve protonsuz silanol (-Si-O-) gruplarının birlikte bulunması, SiNP'lerini suda dağılabilir hale getirir, bu da silika nanopartiküllerinin nonspesifik bağlanması ve in vivo agregasyonunu azaltmak için potansiyeldir. Kanser hücrelerinde aşırı ifade edilen reseptör ligandları; folik asit (FA), laktobiyonik asit, ferritin, hyalüronik asit $(H A)$ ve çeşitli antikorlar mezoporlu silika NP'lerin yüzeyine modifiye edilebilirler (56). Buda antikanser ilaçların tümör dokusunu hedefleme etkisini artırırken, kemoterapötik ilaçların yan etkilerini azaltıp kontrollü tedaviye olanak sağlar. Yapılan araştırmalarda, kolorektal (57), pancreas (58), karaciğer (56), rahim ağzı (59), ovaryum (60) gibi çeşitli kanser türlerinde doksorubisin, kamptotesin, 5-Florourasil (5-FU), paklitaksel ve trastuzumab gibi anti-kanser ilaçların mezoporlu SiNP'lere yüklenmek suretiyle anti-kanser etkinliklerinde artış meydana getirmiştir.

Deng ve ark. kanser tedavisi için tümör nekroz faktörü alfa (TNF- $\alpha$ ) taşıyan hibrit hollow silikakitosan NP'ler geliştirmişlerdir (61). Bu SiNP'ler pH-duyarlı katyonik polisakkarit-kitosan yüzey kaplamasıyla, kanserli hücrelerin büyümesini baskılamak üzere periselüler ve interstisyel ortamda ilaçların kontrollü salımına izin vermişlerdir. SiNP'lere ilaç yüklemede değişik konjugasyon stratejileri araştırılmıştır. Örneğin Schoenfisch grubu, ayarlanabilir boyutlarda ve ilaç salım kinetiğinde nitrik oksit (NO) salgılayan SiNP'leri bildirmişlerdir. NO salımı yapan SiNP'lerin ovaryum tümör hücrelerinde inhibisyonunda artış yaptığı gösterilmiştir (62).

Prasad grubu, suda çözünmeyen, ışığa karşı duyarlı anti kanser ilacı 2-devinil-2-(1heksiloksietil) pirofeophorbid organik olarak $30 \mathrm{~nm}$ SiNP'ler modifiye edip kanser hücrelerinin hücre içine alım davranışlarını ve fotodinamik yöntemle hücrelerin yok edilmesini araştırmışlar ve bu nanopartiküllerin, in vitro ortamda tümör hücrelerini ışığa maruz bırakarak öldüren etkili bir ilaç taşıyıcı sistem olduğunu göstermişlerdir (63).

\section{Demir Oksit Nanopatiküller}

Demir (III) oksit $\left(\mathrm{Fe}_{2} \mathrm{O}_{3}\right)$ kırmızımsı kahverengi, doğada paramanyetik olan inorganik bir bileşiktir ve ayrıca üç ana demir oksitten biridir. Diğer ikisi $\mathrm{FeO}$ ve $\mathrm{Fe}_{3} \mathrm{O}_{4}$ 'tür. Doğada mineral manyetit olarak da ortaya çıkan $\mathrm{Fe}_{3} \mathrm{O}_{4}$, süper paramanyetiktir. Çok küçük boyutları, manyetik özellikleri ve biyouyumlulukları nedeniyle, süper paramanyetik demir oksit nanopartiküller (SPION), kanser, diyabet, ateroskleroz, inflamatuar hastalıkların erken teşhisi için manyetik rezonans görüntüleme (MRI) için geliştirilmiş çözünürlük kontrast ajan, manyetik ilaç rezonans görüntüleme (MRG), hedeflendirilmiş ilaç taşıma, görüntüleme, hipertermi, gen tedavisi, kök hücre izleme, moleküler/hücresel izleme, manyetik ayırma 
teknolojileri (örneğin hızı DNA dizilimi) gibi çeşitli biyomedikal uygulamalarda umut verici olarak ortaya çıkmıştır (52).

Demir oksit nanopartiküller tümör hücresini, NIR gibi non-toksik dalga boyu radyasyonu yoluyla veya ROS üretimini veya hipertermiyi toksik uyaranlara dönüştürebilecek absorbe edilebilecek salınımlı manyetik alanlar ile doğrudan öldürülebilirler.

Genellikle kanserde hipertermi tedavisinde, yüksek manyetik ve radyo-frekans özellikleri nedeniyle demir oksit NP'leri kullanılmaktadır. Demir oksit NP'leri, dekstran gibi farklı polimerlerle kaplama, ligand bağlama ve PEG molekülü ile yüzey fonksiyonelleştirme yoluyla hedeflendirilir bu da stabilite, daha uzun yarılanma ömür sağlar (27).

Huang ve ark. kanser teranostik yaklaşımla hem MRI görüntüleme hem de hedeflendirilmiş ilaç taşıma için demir oksit nanopartikülleri folik asitle konjuge etmişlerdir. MRI için kontrast ajanı ve FA aracılı manyetik hedefli bir ilaç taşıyıcısı olarak DOX yüklü FA-SPION platformunun ilaç taşıma ve antitümör terapi etkinliğini araştırmışlardır.
Asidik pH'da DOX yüklü FA-SPION'ların DOX salımını arttırdığını ve manyetik alan kullanılarak DOX yüklü FA-SPION'ların anti-kanser ilacı tümör dokularına daha etkili hedeflendirdiklerini göstermişlerdir (64).

\section{Sonuç}

Hedeflendirilmiş ilaç taşıyıcı sistemler, kontrollü salım sağlarken terapötik etkinliği artırma ve ilaç lokalizasyonunu iyileştirme, böylece ilaç toksisitesini azaltma potansiyeline sahiptir. Metalik nanopartiküller, hedeflendirilmiş ilaç taşıma ve ilaç geçirgenliğinin arttırılması veya ilk geçiş metabolizmasının üstesinden gelinmesi gibi olanaklar sağlamaktadır. Bununla birlikte bu nanopartiküller, yeni nesil antikanser terapötiklerin taşınmasında aktif olarak araştırılmaktadır. Bu ilaç taşıyıcı sistemlerin kullanımı ile yan etkiler ve direnç gelişimi gibi konvansiyonel terapinin sakıncalarının çoğunun üstesinden gelinebilir. Daha da önemlisi, klinisyenlerin tedavi sırasında tedavinin ilerleyişini ve başarısını izlemenin yanı sıra teşhis etmelerini de sağlayacaktır.

\section{Kaynaklar}

1. Kang YS, Risbud S, Rabolt JF, Stroeve P. Synthesis and characterization of nanometer-size Fe3O4 and YFe2O3 particles. Chem Mater. 1996; 8: 2209-11.

2. Pankhurst QA, Connolly J, Jones S, Dobson J. Applications of magnetic nanoparticles in biomedicine. Journal of physics D: Applied physics. 2003; 36: R167.

3.Dobson J. Gene therapy progress and prospects: magnetic nanoparticle-based gene delivery. Gene Ther. 2006; 13: 283-7.

4. Rudge S, Peterson C, Vessely C, Koda J, Stevens S, Catterall L. Adsorption and desorption of chemotherapeutic drugs from a magnetically targeted carrier (MTC). J Control Release. 2001; 74: 335-40.

5. Appenzeller T. The man who dared to think small. Science. 1991; 254: 1300.

6. Frank G, Langer R, Farokhzad OC. Precise engineering of targeted nanoparticles by using self-assembled biointegrated block coploymers. PNAS 2008; 105 (7): 2586.

7. Chouhan R, Bajpai AK. Real time in vitro studies of doxorubicin release from PHEMA nanoparticles. $J$ Nanobiotechnology 2009; 7 (5): 7.

8. Gelperina S, Kisich K, Iseman MD, Heifets L. The potential advantages of nanoparticle drug delivery systems in chemotherapy of tuberculosis. Am J RespirCrit Care Med. 2005; 172 (12): 1487-90.

9.Susa M, lyer AK, Ryu K, Hornicek FJ, Mankin H, Amiji MM, Duan Z. Doxorubicin loaded Polymeric Nanoparticulate Delivery System to overcome drug resistance in osteosarcoma. BMCCancer 2009; 9: 399-403.

10.Sajja HK, East MP, Mao H, Wang YA, Nie S, Yang L. Development of multifunctional nanoparticles for targeted drug delivery and noninvasive imaging of therapeutic effect. CurrDrugDiscovTechnol 2009; 6: 43-51.

11. Varshosaz J, Farzan M. Nanoparticles for targeted delivery of therapeutics and small interfering RNAs in hepatocellular carcinoma. World J Gastroenterol 2015; 21 (42): 12022-41.

12. Coelho SM. Delivery of biomolecules by functionalized inorganic/organic nanoparticles thesis silvia. Thesis submitted to the University of Porto for a Doctor of Philosophy in Chemical and Biological Engineering. 2013. 
13. Selvan ST, Tan TTY, Yi DK, et al. Functional and multifunctional nanoparticles for bioimaging and biosensing. Langmuir. 2010; 26: 11631-41.

14. Baptista P, Pereira E, Eaton P, Doria G, Miranda A, Gomes I et al. Gold nanoparticles for the development of clinical diagnosis methods. Anal BioanalChem. 2008; 391: 943-50.

15. Hainfeld JF, Dilmanian FA, Slatkin DN, Smilowitz HM. Radiotherapy enhancement with gold nanoparticles. J PharmPharmacol. 2008; 60: 977-85.

16. Mody VV, Siwale R, Singh A, Mody HR. Introduction to metallic nanoparticles. J PharmBioallSci 2010; 2: 282-9.

17. Sau TK, Rogach AL, Jackel F, Klar TA, Feldmann J. Properties and applications of colloidal nonspherical noble metal nanoparticles. Adv Mater 2010; 22: 1805-25.

18.Sperling, RA, RiveraGil, P, Zhang, F, Zanella M, Parak WJ. Biological applications of gold nanoparticles. ChemSocRev 2008; 37: 1896-1908.

19. Chen H, Shao L, Ming T, Sun Z, Zhao C, Yang B, et al. Understanding the photothermal conversion efficiency of gold nanocrystals. Small 2010; 6: 2272-80.

20. Day ES, Morton JG, West JL. Nanoparticles for thermal cancer therapy. J BiomechEng 2009; 131:074001.

21.Piñón-Segundo E, Mendoza-Muñoz N, Quintanar-Guerrero D. Nanoparticles as Dental Drug-Delivery Systems. Nanobiomaterials in Clinical Dentistry 2013; 475-95.

22. Jeevanandam J, Barhoum A, Chan YS, Dufresne A, Danquah MK. Review on nanoparticles and nanostructured materials:history, sources, toxicity and regulations. Beilstein J. Nanotechnol 2018; 9: 1050-74.

23. Yiğit Küçükçobanoğlu Y, Yıldız Aktaş L. Nanokompozit kaynağı ve uygulama alanı olarak bitkiler. Marmara Fen Bilimleri Dergisi 2018; 4: 429-36.

24. Li C, Shuford KL, Park Q, Cai W, Li Y, Lee EJ, et al. High-yield synthesis of single-crystalline gold nanooctahedra. AngewandteChemie 2007; 46 (18): 3264-8.

25. Granqvist CG, Buhrman RA. Ultrafine metal particles. Journal of applied. Physics 1976;47: 2200-19.

26. Malam Y, Loizidou M, Seifalian AM. Liposomes and nanoparticles:nanosized vehicles for drug delivery in cancer. Trends in Pharmacological Sciences 2009; 30 (11): 592-9.

27. Sharma A, Goyal AK, Rath G. Recent advances in metal nanoparticles in cancer therapy. Journal of Drug Targeting 2018; 26 (8): 617-32.

28. Brown SD, Nativo P, Smith JA, Stirling D, Edwards PR, Venugopal B, et al. Gold nanoparticles for the improved anticancer drug delivery of the active component of oxaliplatin. J AmChemSoc 2010;132: 4678-84.

29. Hackenberg S, Scherzed A, Harnisch W, Froelich K, Ginzkey C, Koehler C et al. Antitumor activity of photostimulated zincoxide nanoparticles combined with paclitaxel or cisplatin in HNSCC cellines. J Photochem Photobiol B: Biol. 2012; 114: 87-93.

30.Guo D, Wu C, Jiang H, Li Q, Wang X, Chen B. et al. Synergistic cytotoxic effect of different sized ZnO nanoparticles and daunorubicinagainst leukemia cancer cells under UV irradiation. J Photochem Photobiol B: Biol 2008;93:119-26.

31. Gibson JD, Khanal BP, Zubarev ER. Paclitaxel functionalized gold nanoparticles. J.Am. Chem. Soc 2007; 129 (37): 11653-61.

32. Qian X, Peng XH, Ansari DO, YinGoen Q, Chen GZ, Shin DM et al. Invivo tumor target ingand spectroscopic detection with surface-enhanced Raman nanoparticle tags. Nature biotechnology 2008;26: 83-90.

33. Hwu JR, Lin YS, Josephrajan T, Hsu MH, Cheng FY, Yeh CS et al. Targeted paclitaxel by conjugation to iron oxide and gold nanoparticles. Journal of the American Chemical Society 2009; 131 (1): 66-8.

34. Sershen SR, Westcott SL, Halas NJ, West JL. Temperature-sensitive polymer-nanoshell composites for photo thermally modulated drug delivery. Journal of Biomedical Materials Research 2000;51(3):293-8.

35. Yavuz MS, Cheng Y, Chen J, Cobley MC, Zhang Q, Rycenga M et al. Gold nanocages covered by smart polymers for controlled release with near-infrared light. Nature Materials 2009; 8 (12): 935-9.

36. Eigler DM, Schweizer EK. Positioning single atoms with a scanning tunnellingmicroscope 1990; 344 (6266): 524-6.

37. Kong FY, Zhang JW, Li RF, Wang ZX, Wang WJ, Wang W. Unique roles of gold nanoparticles in drugdelivery, targeting and imaging applications. Molecules 2017; 22: 1445. 
38. Chen YH, Tsai CY, Huang PY, Chang MY, Cheng PC, Chou CH. et al. Methotrexate conjugated to gold nanoparticles inhibits tumor growth in a syngeneic lung tumor model. Mol. Pharmaceut 2007; 4: 713-22.

39. Wang F, Wang YC, Dou S, Xiong MH, Sun TM, Wang J. Doxorubicin-tethered responsive gold nanoparticles facilitate intracellular drug delivery for overcoming multidrug resistance in cancer cells. ACS Nano 2011; 5: 3679-92.

40. Blasiak B, Veggel FC, Tomanek B. Applications of nanoparticles for MRIcancer diagnosis and therapy. J. Nanomater 2013;12.

41.Patra CR, Bhattacharya R, Wang E, Katarya A, Lau JS, Dutta S. et al. Targeted delivery of gemcitabine to pancreatic adenocarcinoma using cetuximab as a targeting agent. Cancer Res 2008; 68: 1970-8.

42. Coelho SC, Almeida GM, Santos-Silva F, Pereira MC, Coelho MA. Enhancing the efficiency of bortezomib conjugated to pegylated gold nanoparticles: An in vitro study on human pancreatic cancer cells and adenocarcinoma human lung alveolar basal epithelial cells. Expert Opin. Drug Deliv 2016; 13: 1075-81.

43. Daduang J, Palasap A, Daduang S, Boonsiri P, Suwannalert P, Limpaiboon T. Gallic acid enhancement of gold nanoparticle anticancer activity in cervical cancer cells. Asian Pac. J. Cancer Prev 2015; 16: 169-74.

44.Bao $\mathrm{H}$, Zhang $\mathrm{Q}$, Xu H, Yan Z. Effects of nanoparticle size on antitumor activity of 10-hydroxycamptotheci nconjugated gold nanoparticles: In vitro and in vivo studies. Int. J. Nanomed 2016; 11: 929-40.

45. Coelho SC, Almeida GM, Pereira M.C, Santos-Silva F, Coelho MA. Functionalized gold nanoparticles improve afatinib delivery into cancer cells. Expert Opin. Drug Deliv 2016; 13: 133-41.

46. Sironmani A, Daniel K. Silver Nanoparticles - Universal Multifunctional Nanoparticles for BioSensing, Imaging for Diagnostics and TargetedDrug Delivery for Therapeutic Applications. Drug Discovery and Development Present and Future 2011; 463-84.

47.Prashob Peter KJ. Multi-Functional Silver Nanoparticles for Drug Delivery: A Review. Int J Cur Res Rev 2017; 9 (8).

48. Pugazhendhia A, Edison TNJI, Karuppusamy I, Kathirvel B. Inorganic nanoparticles: A potential cancer therapy for human welfare. International Journal of Pharmaceutics 2018; 539: 104-11.

49. Sadat Shandiz SA, Shafiee Ardestani M, Shahbazzadeh D, Assadi A, Ahangari Cohan R, Asgary V et al. Novel imatinib-loaded silver nanoparticles for enhanced apoptosis of human breast cancer MCF-7 cells. Artif Cells Nanomed Biotechnol 2017; 45: 1-10.

50. Goyal G, Hwang J, Aviral J, Seo Y, Jo Y, Son J et al. Green synthesis of silver nanoparticles using b-glucan, and their incorporation into doxorubicinloaded water-in-oil nanoemulsions for antitumor and antibacterial applications. J Ind Eng Chem 2016; 47: 179-86.

51. Lewis and Harrison, LLC. Generally recognized as safe determination for silicon dioxide when added directly and/or Indirectly to human food [Internet]. Fda 2010 [cited 9 August 2015]. Available from: http://www.fda.gov/ucm/groups/fdagov-public/@fdagov-foods-gen/documents/document/ucm269494.pdf.

52. Pandey P, Dahıya M. A Brıef review on ınorganıc nanopartıcles. J Crit Rev 2016; 3 (3):18-26.

53. Giret S, Wong Chi Man M, Carce C. Mesoporous-silica-functionalized nanoparticles for drug delivery. Chem. Eur. J. 2015; 21: $13850-65$.

54. Desai D, Prabhakar N, Mamaeva V, Karaman DŞ, Lähdeniemi IA, Sahlgren C et al. Targeted modulation of cell differentiation in distinct regions of the gastrointestinal tract via oral administration of differently PEG-PEI functionalized mesoporous silica nanoparticlesInternational Journal of Nanomedicine 2016; 11: 299-313.

55. Yesil-Celiktas O, Pala C, Cetin-Uyanikgil EO, Sevimli-Gur C. Synthesis of silica-PAMAM dendrimer nanoparticles as promising carriers in Neuro blastoma cells. Analytical Biochemistry 2017; 519: 1-7.

56. Xu, X., Wu, C., Bai, A., Liu, X., Lv, H., Liu, Y. Folate-functionalized mesoporous silica nanoparticles as a liver tumor-targeted drug delivery system to improve the antitumor effect of paclitaxel. Journal of Nanomaterials 2017.

57.Gary-Bobo M., Brevet D, Benkirane-Jessel N, Raehm L, Maillard P, Garcia M. et al. Hyaluronic acidfunctionalized mesoporous silica nanoparticles for efficient photodynamic therapy of cancer cells. Photodiagnosis and Photodynamic Therapy 2012; 9: 256-60.

58. Lu J, Li Z, Zink JI, Tamanoi F. In vivo tumor suppression efficacy of mesoporous silica nanoparticles-based drug-delivery system: enhanced efficacy by folate modification. Nanomedicine: Nanotechnology, Biology, and Medicine 2012; 8: 212-20. 
59. Chen WH, Luo GF, Lei Q, Cao FY, Fan JX, Quu WX. Rational design of multifunctional magnetic mesoporous silica nanoparticle for tumor-targeted magnetic resonance imaging and precise therapy. Biomaterials 2016; 76: 87-101.

60.Zheng T, Wang A, Hu D, Wang Y. Tumor-targeting templated silica nanoparticles as a dual-drug delivery system for anti-angiogenic ovarian cancer therapy. Experimental and Therapeutic Medicine 2017; 14: 2162-70.

61.Deng ZW, Zhen ZP, Hu XX, Wu SL, Xu ZS, Chu PK. Biomaterials 2011; 32: 4976-86.

62. Stevens EV, Wells A, Shin JH, Liu J, Der CJ, Schoenfisch MH. Nitric oxide-releasing silica nanoparticle inhibition of ovarian cancer cell growth. Mol Pharm 2010; 7 (3): 775-85.

63. Roy I, Ohulchanskyy TY, Pudavar HE, Bergey EJ, Oseroff AR, Morgan J. et al. Ceramic-Based Nanoparticles Entrapping Water-Insoluble Photosensitizing Anticancer Drugs: A Novel Drug-Carrier System for Photodynamic Therapy. J.Am .Chem.Soc. 2003; 125: 7860-5.

64. Huang Y, Mao K, Zhang B, Zhao Y. Superparamagnetic iron oxide nanoparticles conjugated with folic acidfor dual target-specific drug delivery and MRI in cancer theranostics. Materials Science and Engineering C 2017; 70: 763-71. 